Katarzyna Szalewska

Wydział Filologiczny

Uniwersytet Gdański

e-mail: k.szalewska@ug.edu.pl

\title{
Pejzaż dźwiękowy i praktyki audytywne czasu wojny (wówczas i współcześnie) ${ }^{1}$
}

„Tak grzejąc siebie, jeszcze bardziej się rozżarli: / Wzmaga się zgiełk, szczękają żelazne oszczepy, / Dźwięk ich bije o nieba miedzianego sklepy"2 - $\mathrm{w}$ ten sposób Trojanie szykują się do walki z Grekami po śmierci Patrokla. Tukidydes natomiast notuje w Wojnie peloponeskiej: „Zaczęła się bitwa. Argiwczycy i sprzymierzeńcy szli ostro i gwałtownie, Lacedemończycy powoli, przy dźwiękach licznych fletów; nie jest to u nich zwyczaj religijny, lecz sposób na utrzymanie rytmu w marszu, aby nie załamał się szyk bojowy, jak to często się zdarza przy natarciu dokonywanym przez wielkie armie" $^{\prime \prime}$. Choć w najstarszych opisach batalistycznych doznania i metafory akustyczne nie odgrywają pierwszorzędnej roli, jak dzieje się to $\mathrm{w}$ przypadku świadectw $z$ drugiej wojny światowej, to jednak wojna zawsze wiąże się z dźwiękiem. Specyficzna dla owego nie-czasu audiosfera nieczęsto zyskuje należytą uwagę historiografów, z wyjątkiem monografii poświęconych propagandowym działaniom władz totalitarnych. Jedna $z$ omawiających to zagadnienie historyczek, Carolyn Birdsall, pisze w kontekście miejskiego pejzażu Niemiec lat 1933-1945 o roli dźwięku w dyskursie władzy, używając terminu „ikon dźwiękowych" - sonic icons, silnie powiązanych ze stereotypami współkształtującymi w naszej kulturze historycznej wyobrażenia na temat

1 Publikacja powstała przy wsparciu finansowym Fundacji na rzecz Nauki Polskiej.

2 Homer, Iliada, przeł. F.K. Dmochowski, objaśnił J. Korpanty, Kraków 1972, s. 225.

3 Tukidydes, Wojna peloponeska, przeł. K. Kumaniecki, Wrocław 2004. 
narodowego socjalizmu ${ }^{4}$. Jakkolwiek proponowany termin wydaje się oksymoronem, nietrudno wskazać te z wojennych dźwięków, które - powtarzane $\mathrm{w}$ niezliczonych reprodukcjach - stają się funkcjonującymi w nowoczesnym pejzażu kulturowym dźwiękami-znakami. Dźwięk bowiem, z jednej strony, podobnie jak obraz, podlega „ikonizacji”, bardziej trafnie - podobnie jak literacki motyw podatny jest na petryfikację, okrzepnięcie $\mathrm{w}$ formie i przypisanemu jej znaczeniu. Z drugiej strony dźwięk ma siłę katalizatora procesu pamięci, $\mathrm{w}$ tym sensie, $\mathrm{w}$ jakim poszczególne tony łączą się z wydarzeniami, dla których tło budują. Obie te prawidłowości bardzo wyraźnie uwidaczniają się $\mathrm{w}$ zapisach wojennych wspomnień.

Expressis verbis rolę dźwięku w doświadczeniu wojny formułuje Henryk Waniek w eseju o znaczącym tytule Próbka wojny w eterze:

Moje jedyne osobiste wspomnienie drugiej wojny światowej jest ściśle dźwiękowe. Był to huk niedomkniętych drzwi schronu przeciwlotniczego, jakie zatrzasnęły się wskutek wybuchu bomby. Mogły być inne dźwięki towarzyszące - zawodzenie syren alarmowych, albo dźwięki silników dziewięćdziesięciu sześciu amerykańskich bombowców, które wystartowały we Włoszech, by 13 września 1944 roku zaatakować zakłady IG Farben w Monowicach, gdzie znajdowała się filia obozu Auschwitz. Mogły być dźwięki artylerii przeciwlotniczej, która nie próżnowała w takich wypadkach; huki wybuchów; okrzyki trwogi. Ale w mojej pamięci został tylko ten dźwięk metalowych drzwi schronu, które zatrzasnęły się i zapanowała ciemność 5 .

Takich świadectw znaleźć można bardzo wiele we współczesnej literaturze, której autorzy reprezentują wspólnotę wojennych doświadczeń akustycznych. Radiowe transmisje przemówień Hitlera, dźwięki syren przeciwlotniczych, piosenki warszawskiej ulicy czasu wojennego, dźwięk katiuszy, sfrazeologizowany już "chrzęst oręża" - to tylko niektóre ze spetryfikowanych odgłosów wojny, powielanych jako dźwięki-znaki wydarzeń (w tym wypadku drugiej wojny światowej), których przywołanie ewokuje reprezentowane przez akustyczny zapis doświadczenie. Raymond Murray Schafer, jeden z prekursorów tak zwanej ekologii dźwięku (acoustic ecology), proponuje sformułowanie - na wzór krajobrazu (landscape) - terminu pejzaż dźwiękowy (soundscape) ${ }^{6}$. Byłyby nim wszelkie bodźce słuchowe, od muzycznej kompo-

4 C. Birdsall, Nazi Soundscapes. Sound, Technology and Urban Space in Germany, 1933-1945, Amsterdam 2012, s. 30.

${ }^{5}$ H. Waniek, Próbka wojny w eterze, www.silesia-schlesien.com/index.php?option=com_ content\&view=article\&id=237:henryk-waniek-probka-wojny-w-eterze [dostęp 21.08.2014].

6 Zob. R. Murray Schafer, The Soundscape: our sonic environment and the tuning of the world, Rochester 1993. 
zycji, przez program radiowy, po dźwięki natury. Tak skonstruowana audiosfera, stanowiąc tło codziennych czynności jej słuchacza, przesądzałaby - na równi z rzeczywistością widzialną - o specyfice kulturowego doświadczenia. Natomiast od otaczającej nas wszystkich fonosfery, soundscape odróżniałby się właśnie owym kulturowym idiomem - będąc właściwym dla danej kultury $\mathrm{w}$ danym momencie historii.

Schafer jest jednocześnie jednym z pierwszych promotorów dowartościowania aspektu dźwiękowego w badaniach historycznych. Rzecz jasna, ogromne znaczenie dla metodologii studiów nad pejzażem akustycznym przeszłości ma dostęp do archiwaliów dźwiękowych, z oczywistych względów uprzywilejowujący badania nad konfliktami XX stulecia. Autor The Tuning of the World proponuje jednak, być może naiwne $\mathrm{w}$ perspektywie klasycznej historiografii opartej na autorytecie źródeł, ale sprzyjające literaturoznawstwu rozwiązanie. Wprowadza on bowiem postać świadka/słuchacza (earwitness), który przekazuje akustyczne doświadczenie poprzez dyskurs. Nie wszyscy są jednak wiarygodnymi rewelatorami dźwięku - Schafer wymienia w pierwszym rzędzie Remarque'a, Faulknera, Tołstoja, Hardy'ego i Manna. Jakkolwiek subiektywny jest to ranking, twórca akustycznej ekologii zwraca uwagę na specjalny talent świadków/słuchaczy do utrwalania audiosfery $\mathrm{w}$ języku, reprezentacji doświadczenia bycia w określonym czasie i miejscu, tworzenia „opisów konstytuujących najlepszy $\mathrm{z}$ dostępnych przewodników w rekonstrukcji dźwięków przeszłości (soundscapes past)" 7 .

Współczesna literatura polska obfituje w relacje świadków/słuchaczy. Zacytowany Waniek nie jest jedynym pisarzem, w którego autobiograficznym zapisie lat 1939-1945 ważną rolę odgrywają dźwięki charakterystyczne dla czasu wojny. Zdaje się, że to raczej interpretatorzy wojennej prozy, zgodnie z (po)nowoczesnym zainteresowaniem antropologicznymi wymiarami doświadczenia historycznego, odkrywają nowe aspekty reprezentacji codzienności życia w czasie wojny. Literatura polska, dla której temat wojenny jest szczególnie istotny i wciąż zajmuje centralne miejsce zarówno pod względem tematycznym, jak i problemowym, stanowi bardzo bogate źródło do badań pejzażu dźwiękowego lat 1939-1945. Taka lektura autobiograficznych zapisów (umożliwiających ujmowanie wypowiadającego podmiotu jako świadka/słuchacza - earwitness - doświadczeń, o których pisze) czerpie inspirację nie tylko $\mathrm{z}$ mikrohistorii i zainteresowania dziejami codzienności, ale również z geografii sensorycznej, dociekającej roli zmysłów w percypowaniu

\footnotetext{
7 R. Murray Schafer, The Soundscape: our sonic environment and the tuning of the world, s. 9.
} 
przestrzeni. Literackie opisy audytywne stanowią przy tym nie tylko źródło do badania kulturowego doświadczania wojny (i pamięci o niej), ale również są ciekawym przykładem zmagania się $\mathrm{z}$ materią słowa $\mathrm{w}$ celu znalezienia najlepszej techniki deskrypcji doświadczeń słuchowych.

Najwybitniejszym "słuchaczem” w polskiej literaturze jest bez wątpienia Miron Białoszewski, twórca wyjątkowo wrażliwy na dźwięk - zarówno ten wojenny, jak i poetycki. Stąd jego eksperymentalny w formie Pamiętnik $z$ powstania warszawskiego to nie tylko dokument zmagania $\mathrm{z}$ traumatyczną pamięcią, ale również z onomatopeicznym wymiarem słowa:

Ta groza. Dzienna. Samoloty przylatywały. Czyli zniżały się nad dachy. I wtedy, jak już było słychać, że są... drrrrr... i zlatują nad nasze dachy, naszych bloków albo nad najbliższe, to wiadomo było, że i bomby. I zaraz od tego świdrowania z góry na dół samolotowego odłączało się wycie bomby; chwilę się czekało, ale króciutką. Ta chwila to było samo trafienie. A dalej huk, czyli wybuch. I dalej - łomot, trzask, rozsypywanie się czegoś, czyli skutki trafienia ${ }^{8}$.

Pamiętnik... jest książką szczególną dla badaczy zmysłowego aspektu doświadczenia wojny. Białoszewski bowiem nie tylko rejestruje odgłosy, ale także próbuje znaleźć dla nich ekwiwalent słowny, sięgając po liczne onomatopeje, aliteracje i inne środki organizacji brzmieniowej, elipsy oznaczające $\mathrm{w}$ jednych miejscach przerwy $\mathrm{w}$ sygnale, $\mathrm{w}$ innych $\mathrm{z}$ kolei (wraz $\mathrm{z}$ solecystyczną składnią) - trudną do zniesienia ciągłość dźwięku. Nadto te miniaturki onomatopeiczne komponuje $\mathrm{w}$ większe segmenty mające dużą siłę oddziaływania, kumulujące znaczenia, jak choćby scena, którą przedstawia powyższy fragment, w całości zbudowana na nachodzących na siebie dźwiękach nadlatujących samolotów, wybuchających bomb, ciszy i modlitwy odprawianej $w$ ruinach. Białoszewski nie tylko reprezentuje jedno $z$ najczęściej obecnych $\mathrm{w}$ relacjach świadków doświadczenie nalotu (a także, w innych miejscach, jak wielu eartwitness, przywołuje sceny zgadywania po sygnale rodzaju samolotu), ale również próbuje oddać poprzez zapis traumę nasłuchiwania. To właśnie nasłuchiwanie, a nie słuchanie czy podsłuchiwanie, stało się podstawową praktyką audytywną czasu wojny. Nałkowska zapisuje w dzienniku pod datą 10 września 1939: „Wszyscy chowają się do domu i pod drzewa przy nalocie, nasłuchują, czy leci bombowiec,

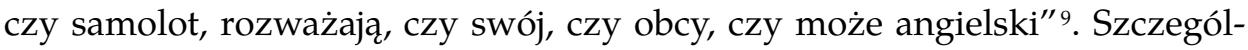
nie wyraźnie uwidacznia się to $\mathrm{w}$ autobiograficznych zapisach żydowskich

\footnotetext{
8 M. Białoszewski, Pamiętnik z powstania warszawskiego, Warszawa 2007, s. 62.

9 Z. Nałkowska, Dzienniki czasu wojny, Warszawa 1972, s. 39.
} 
dzieci, ukrywających się przed nazistami, tak jak Roma Ligocka, która w autobiograficznej Dziewczynce w czerwonym płaszczyku wspomina:

Przyjdą po nas w nocy i nas zabiorą. Myślę o tym za każdym razem, kiedy na schodach słyszę oficerki, ochrypłe szczekanie psów i wrzeszczących mężczyzn. [...]. Muszę spać, myślę. A wtedy znowu ich słyszę. [...]. Ludzie krzyczą, psy szczekają, mężczyźni wrzeszczą ${ }^{10}$.

Trzyczłonowe, oparte na asyndetonie wyliczenie kończące przytoczony fragment pokazuje pulsowanie dźwięku, pojawianie się kolejnych tonów tej wojennej melodii grozy. Ukrywającemu się dziecku pozostaje trwożne nasłuchiwanie - samo musi trwać w ciszy, by nie wydać swojej kryjówki, dźwięk znajduje się po stronie oprawców. W wojennych relacjach staje się on synonimem władzy i antycypacją nadchodzącego zagrożenia. Nałkowska notuje 15 października 1943, ustanawiając głośnik centrum kataklizmu: „Przychodzi rano Genia i powtarza, co słyszała przez głośnik. Wymieniają cały szereg nazwisk ludzi rozstrzelanych dziś rano. Później nazwiska tych, którzy rozstrzelani będą, o ile nie ustaną zamachy"11.

Henri Lefebvre i Michel de Certeau ${ }^{12}$ piszą o praktykach przestrzennych, które rozumieją jako działania podejmowane przez podmiot $\mathrm{w}$ przestrzeni jego codzienności (ścieżki chodzenia, prywatne kartografie, emocje związane z przestrzenią, podejmowane w niej działania itd.). Myślę, że analogicznie można mówić o praktykach audytywnych. Chodziłoby tu o sposoby wytwarzania, ale przede wszystkim odbierania i interpretowania dźwięku w określonej czasoprzestrzeni. Pisząc zaś o praktykach audytywnych czasu wojny, analogicznie do właściwych jej praktyk przestrzennych ${ }^{13}$, uwzględnić należy zasadniczą ich nieprzystawalność do tych znanych i podejmowanych w czasie pokoju. Wrażenie tej unikatowości i niepowtarzalności w późniejszej biografii znajduje swój wyraz w licznych relacjach osobistych. Dotyczy to zarówno audiosfery publicznej, jak i prywatnej. Jak zauważa Birdsall,

10 R. Ligocka, współpraca I. von Fickenstein, Dziewczynka w czerwonym płaszczyku, przeł. K. Zimmerer, Kraków 2013, s. 26-27.

11 Z. Nałkowska, Dzienniki czasu wojny, s. 313.

12 Zob. M. de Certeau, Wyznaleźć codzienność: sztuki działania, przeł. K. Thiel-Jańczuk, Kraków 2008; H. Lefebvre, The Production of Space, trans. D. Nicholson-Smith, Oxford 1991, s. 8-67, passim. Lefebvre definiuje praktyki przestrzenne (spatial practices) jako te, które "obejmują produkcję i reprodukcję, a także poszczególne umiejscowienia i uwarunkowania przestrzenne charakterystyczne dla każdej formacji społecznej" (tamże, s. 33).

13 Zob. K. Szalewska, Przestrzeń i wojna. Perspektywy lektury kartografii wojennej, „Białostockie Studia Literaturoznawcze" 2012, nr 3. 
Te [wojenne - dop. K.S.] zmiany w słuchaniu są bezpośrednio związane z rozwojem nowoczesnych form technologii. Wraz z widocznym wpływem industrializacji i nowych sieci transportu, technologiczna zmiana wiązała się również z popularnymi (i często głośnymi) wrażeniami takimi jak filmowe obrazy, balony na ogrzane powietrze, wyścigi samochodowe, sterowce Zeppelin i samoloty. Mechaniczna muzyka od roku 1880 oznacza szeroką gamę akustycznych atrakcji, takich jak katarynki, akordeony, pianola i gramofon. Wybuch I wojny światowej w 1914 roku także jest opisywany w kategoriach technologicznej „brutalizacji" pejzażu dźwiękowego [...]. Przytłaczające dźwięki nowoczesnej wojny z pociskami, bronią i artylerią - były wytwarzane z intensywnością, jakiej nie doświadczano i nie wyobrażano sobie wcześniej. Ten pejzaż, zdominowany przez „technologiczne brzmienie" wojny stał się podstawą do niepokoju, nierzadko do trwałej traumy, tych, którzy byli poddani jego nieustającemu, przytłaczającemu jednostkę hałasowi ${ }^{14}$.

Nowe dźwięki, związane z rozwojem technologii, bardzo szybko dominują w krajobrazie dźwiękowym początku XX stulecia. Powtarzającymi się $\mathrm{w}$ autobiograficznych zapiskach, ale też $\mathrm{w}$ popkulturowych obrazach wojny, motywami są akordeon (w polskich relacjach stopizowany jako atrybut żołnierzy radzieckich, ale przecież nie tylko), gramofon i wreszcie - radio. Są to, podobnie jak dźwięk syren alarmowych i nadlatujących bombowców, obrazy-figury (sonic icons) kształtujące nowoczesne wyobrażenie o pejzażu dźwiękowym czasu drugiej wojny światowej. Tę prawidłowość, a szczególnie ogromną rolę radia, problematyzuje Waniek w eseju Próbka wojny w eterze:

Pamiętam z dzieciństwa - bo lubiłem ją oglądać - mapę Europy, na której czerwoną kredką, jakaś ręka oznaczała ruchy frontów, zgodnie z radiowymi komunikatami wojennymi. Bo radio $\mathrm{w}$ tamtych czasach, oprócz tego, że było źródłem informacji, stanowiło również jedną z niewidzialnych, ale bardzo treściwych, przestrzeni wojennych. W miarę jak nabywałem wiadomości o drugiej wojnie światowej, a w szkolnej edukacji także o innych wojnach, utrwalało się we mnie przekonanie, że są to najbardziej hałaśliwe epizody historii. Było tak już w prehistorii - świst strzał wystrzeliwanych z łuku lub kuszy, uderzenia pałek, maczug czy włóczni, które dopełniano groźnymi dźwiękami. Wojenne okrzyki, śpiewy, zawodzenia rogów też były bronią. Legendarnym tego wyrazem jest biblijny opis zdobycia miasta Jerycho, dwukrotnie wspomniany w Biblii, którego mury skruszono przy pomocy dźwięku trąb. Rozwój techniki militarnej wprowadził instrumenty walki, które miały nie tylko zwielokrotnioną moc niszczącą, ale posiadały szczególną charakterystykę dźwiękową, a więc szeroki wachlarz broni palnej, prostej i maszynowej, artyleryjskiej i rakietowej, lotnictwo wojskowe. To utwierdzało mnie w przekonaniu, że dźwięki

14 C. Birsdall, Nazi Soundscapes, s. 15. 
stanowią ważny składnik walki i mają bezpośrednie zastosowanie bitewne. Po tysiącleciach, obok innych świeżych wynalazków, rola militarna przypadła też radiofonii, którą po pierwszej wojnie światowej wprowadzono do repertuaru technik wojennych ${ }^{15}$.

W relacji Wańka dostrzec można bardzo znamienną prawidłowość, która pozwala sobie uzmysłowić zasadność oksymoronicznego z pozoru terminu pejzaż dźwiękowy (soundscape). Radio, jako „niewidzialna, ale bardzo treściwa, przestrzeń wojenna”, zostaje synestezyjnym gestem skojarzone z mapą (zresztą ikoniczną tym razem figurą wojny ${ }^{16}$ ), podobnie jak ona odnosi się bowiem do wymiaru spacjalnego - tworzy audytywną przestrzeń wojennej codzienności. A dla niej-dodajmy - jedną z głównych form nasłuchiw ania było właśnie gromadzenie się wokół radia jako źródła informacji, zagrożeń lub nadziei. W tym sensie radio stanowi metonimiczny odpowiednik doświadczenia wojny.

Nałkowska notuje w Dzienniku pod datą 2 września 1942 roku:

"Alarm ogłaszają" - wołała przez drzwi. W pierwszej chwili usłuchałam, ale zrobiło mi się żal ciepłej wody, tak trudnej teraz do złapania, i wróciłam do wanny. Powtarza się znajoma sceneria: za oknem zawisają nagle jasne wśród nocy światła, zimno płonące, jak na choince, wiszą długo, zamieniając całe dzielnice nocy $\mathrm{w}$ dzień swym blaskiem spokojnym. [...]. Pohukiwania nurkujących i pikujących bombowców, płaska strzelanina przyziemna, małe, częste błyskawice armatnich strzałów. Światła wisiały blisko i blisko mruczały bombowce, ale bomby na ten raz spadały daleko i było ich znacznie więcej ${ }^{17}$.

Audytywne praktyki wojenne to przede wszystkim powtarzające się w bardzo licznych świadectwach - słuchanie radia i alarmów przeciwlotnicznych, co poświadczają badania prowadzone wśród różnonarodowych

15 H. Waniek, Próbka wojny w eterze, www.silesia-schlesien.com/index.php?option=com_ content\&view=article\&id=237:henryk-waniek-probka-wojny-w-eterze [dostęp: 21.08.2014].

16 Pisze o tym Elżbieta Konończuk: „Mapa z liniami granic narysowanymi kopiowym ołówkiem - wizualizująca proces zawłaszczania terytorium - staje się przykładem użycia jej jako narzędzia władzy i panowania. "Mapy są obrazem władzy« - jak pisze Schlögel - analizując znane $\mathrm{z}$ historii sceny $\mathrm{z}$ udziałem przywódców, rozgrywające się przy stole z mapą. Niemiecki uczeń [chodzi o opowiadanie Stefana Chwina Białe kafelki, porcelana, nikiel - K.S.], młody użytkownik atlasu, przypomina zatem stratega patrzącego z góry na obraz terytorium, na którym toczy się walka. Ołówkiem oznacza jej zwycięski przebieg, symbolicznie biorąc w niej udział, a tym samym stając się odpowiedzialnym - jak postrzega to narrator - za spalenie domu babci na Mokotowie" (E. Kononczuk, Mapa w interdyscyplinarnym dialogu geografii, historii i literatury, „Teksty Drugie" 2011, nr 5, s. 260).

17 Z. Nałkowska, Dzienniki czasu wojny, s. 272. 
świadków kataklizmu. Trauma, która ma charakter audytywny, wiąże się bowiem silnie z pojęciem pamięci autobiograficznej ${ }^{18}$. Dotyczy ona jednak również sfery publicznej, której pejzaż dźwiękowy, zbrutalizowany w XX wieku, zawiera w sobie także pamięć osób i ich głosów. „W radio słychać głos z Warszawy, odwołujący alarm lotniczy, oraz przemówienie Starzyńskiego: zagrzewa ludność do męstwa i obrony, zaleca uprzątanie gruzu ze zwalonych domów, uprzątanie gnijących odpadków z ulic i podwórzy, otwieranie sklepów"19 - notuje Nałkowska 10 września 1939 roku, dokumentując jeden z głosów epoki, które wplotły się nierozerwalnie w ówczesny publiczny warszawski pejzaż audytywny. (Odmiennym przykładem może być choćby powielane $w$ licznych filmach wojennych, emitowane przez radio przemówienie Hitlera, które funkcjonuje także w kulturze popularnej jako głos/znak kataklizmu).

Dźwięk nie tylko może przywoływać określone zdarzenia, ale także stawać się ich „interpretantem”. Dzieje się tak choćby w Kręgach obcości, autobiografii Michała Głowińskiego:

Tego lata przeszła nad Warszawą wielka, nadzwyczaj intensywna burza, która oczywiście nie dzieliła miasta na stronę aryjską i dzielnicę żydowską. Dzięki wspaniałemu dziełu Barbary Engelking i Jacka Leociaka, będącemu kroniką warszawskiego getta, wiem, kiedy nawiedziła ona te strony. Stało się to w czwartek, 3 września 1942 roku (wieczorem), a więc wtedy, gdy akcja likwidacyjna znajdowała się $\mathrm{w}$ pełnym toku. Burza była - potwierdzają to także autorzy - potężna. Niebo rozpalało się od błyskawic, a pioruny waliły jeden za drugim z nasilającą się gwałtownością. [...]. Momentami sądziłem, że uderzenia mocne i silne zmierzają ku nam, którzy tu jesteśmy. Bałem się, tak jak bałem się jakiś czas wcześniej, gdy nad Warszawę nadleciały rosyjskie samoloty i zrzucały bomby. Też było dużo huku, dominowały mieszane uczucia. Radości, że coś się dzieje i ktoś wreszcie wali w Niemców, towarzyszyły obawy, że zbłąkana bomba trafi $w$ nas, dokona aktu zniszczenia, a my wszyscy zginiemy od razu bądź znajdziemy się pod gruzami ${ }^{20}$.

Audytywne doświadczenie wojny oznacza bezgłośne nasłuchiwanie (jak w relacjach ukrywanych Żydów), gromadzenie się wokół źródła dźwięku/informacji (jak w powtarzających się w tekstach scenach włączania radia), nadawanie dźwiękowi cech znaczącego (jak podczas zgadywania typu samolotu opisanego choćby przez Białoszewskiego), ale

18 O kategorii pamięci autobiograficznej zob. D. Draaisma, Dlaczego życie płynie szybciej, gdy się starzejemy. O pamięci autobiograficznej, przeł. E. Jusewicz-Kalter, Warszawa 2006.

19 Z. Nałkowska, Dzienniki czasu wojny, s. 38.

20 M. Głowiński, Kręgi obcości. Opowieść autobiograficzna, Kraków 2010, s. 64-65. 
przede wszystkim utożsamianie dźwięku z władzą i zagrożeniem (rzadko z nadzieją). Aktywność pozostaje po stronie oprawców, to oni są wytwórcami coraz mocniej zbrutalizowanej audiosfery, o której pisała Birdsall, a której właściwości tak trafnie uchwycił Günter Grass w Blaszanym bębenku, oddając marszową euforię zwolenników nazizmu. Ofiary totalitaryzmów odgrywają w krajobrazie dźwiękowym wojny rolę bierną, są przedmiotem audytywnej aktywności, a ich jedyne możliwe praktyki sprowadzają się do słuchania.

Elżbieta Rybicka, komentując koncepcję soundscape'u Schafera i proponując, zresztą analogiczne $\mathrm{w}$ dużej mierze, pojęcie sonotopografii, pisze o dwóch modelach reprezentacji doświadczenia dźwiękowego w literaturze współczesnej:

W opisie krajobrazu dźwiękowego, a więc sonotopografii, można wyróżnić dwie tendencje, pierwsza zmierza do onomatopeizacji deskrypcji, a więc naturalizacji opartej na szukaniu jak najbardziej bezpośrednich ekwiwalentów percepcji słuchowej [...]. W drugiej natomiast dużą rolę odgrywa metaforyka muzyczna, która organizuje, a zarazem tworzy ramę interpretacyjną sfery dźwiękowej, przyrodnicze i cywilizacyjne wrażenia audytywne są bowiem postrzegane jako symfonia, kantata czy chór ${ }^{21}$.

W przypadku relacji wojennych te dwie perspektywy nachodzą na siebie. $Z$ jednej strony świadkowie dźwięku próbują oddać grozę, sięgając po dźwiękonaśladownicze zabiegi, z drugiej podlegają one kulturowej interpretacji i literackiemu opracowaniu. Dźwięk nie jest już więc neutralny, staje się semiotycznym komunikatem. Obie tendencje wyraźnie widać w Pamiętniku... Białoszewskiego, któremu chwyty retoryczne (takie jak wspominane: anakolut, solecyzm, onomatopeje, elipsy, wykrzyknienia czy przewaga parataksy nad hipotaksą) pozwalają oddać tempo wojennych doświadczeń, wybijane przez odgłosy kataklizmu. Jednak ten sam autor kształtuje językowy materiał w sposób wskazujący na artystyczny zamysł, istnienie interpretacyjnej ramy. Dzieje się tak choćby we fragmencie, w którym dźwięki bombardowania zostają zestawione z melodią słów modlitewnych:

I odmawianie. To mało. Śpiewanie. To dopiero.

Pod Twoją obroonę uuciekamy się...

$[\ldots]$

21 E. Rybicka, Geopoetyka. Przestrzeń i miejsce we współczesnych teoriach i praktykach literackich, Kraków 2014, s. 250. 
Nagle głośniej, bomby i

Najświętsze Serce Jezusa,

zmiłuj się nad nami.

[...]

Walenie, latają ściany ${ }^{22}$.

Taka kontaminacja pozwala na oddanie $\mathrm{w}$ jednym obrazie ruchu wertykalnego dźwięku - płynącego z gruzów ku niebu błagania biernych uczestników praktyk audytywnych (którzy próbują zyskać aktywność i wpływ na przebieg zdarzeń poprzez wypowiadaną modlitwę) oraz - w odwrotnym kierunku - odgłosu bomb.

Literackie konstrukcje krajobrazu dźwiękowego szczególne miejsce zajmują, rzecz jasna, w poezji. Jeden z najbardziej znanych utworów tego czasu, Alarm Antoniego Słonimskiego, jest przecież właśnie zapisem jednej z wojennych ikon dźwiękowych - alarmu przeciwlotniczego. Czytamy w liryku: „brzęczy, brzęczy, szumi i drży. / I pękł. / Głucho w głąb. / Raz, dwa, trzy. / Seria bomb" 23. Tutaj także dźwięk zostaje oddany poprzez onomatopeiczne czasowniki, ułożone asyndetonicznie, co imituje narastanie i fazowość dźwięku. I tu również przyjęcie perspektywy wertykalnej (w głąb) przypomina o źródle najstraszniejszego z wojennych odgłosów, którego groza została dodatkowo zintensyfikowana "ostrym” rymem oksytonicznym. Jak pisze cytowana już autorka Nazi Soundscapes...:

O ile opisy końca wojny podkreślają ciszę i nieobecność, wojenny pejzaż dźwiękowy był silnie zdominowany przez trzy główne dźwięki - syren, samolotów i ataków bombowych. W istocie różne kombinacje tych głośnych wojennych dźwięków - przeplatane okresami ciszy - tworzyły codzienny pejzaż dźwiękowy centrów miast takich jak Düsseldorf. Dźwięki te zdominowały prawie wszystkie inne aspekty miejskiej audiosfery, chociaż zadziwia również sposób, $\mathrm{w}$ jaki te niepokojące sygnały (i ich znaczenie - związek dosłownie z życiem i śmiercią) stawały się dla słuchaczy normą i sprowadzane były do roli tła dla innych bodźców ${ }^{24}$.

To wplecenie odgłosów wojny w codzienny pejzaż praktyk audytywnych jest znakiem historii miasta, która staje się możliwa do odtworzenia przede wszystkim poprzez indywidualne zapisy, jak te, wyżej cytowane, wyznania świadków dźwięku (earwitness), ale stanowi również element współczesnych działań audytywnych i kształtowania polityki historycznej, co ma ogromne znaczenie dla analizy dzisiejszych praktyk kulturowych.

22 M. Białoszewski, Pamiętnik z powstania warszawskiego, s. 83-84.

23 A. Słonimski, Alarm, w: tegoż, 138 wierszy, Warszawa 1973.

24 C. Birdsall, Nazi Soundscapes, s. 129. 


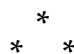

W koncepcji Schafera „,[...] znak dźwiękowy (ang. soundmark) jest pojęciem ukutym na wzór znaku krajobrazowego, wizualnego (ang. landmark) i odnosi się do brzmienia, które jest unikatowe dla danej społeczności i posiada właściwości czyniące go zauważalnym przez wspólnotę"25. Według badacza soundmarks stanowią warte rejestracji i zachowania dźwięki będące dziedzictwem kulturowym wspólnoty, tworzące specyficzny dla danych miejsc krajobraz dźwiękowy - soundscape. Tę rolę spełniają zwłaszcza dźwięki łatwo wyróżnialne, jak właśnie syreny czy dawniej - dzwony. Tym, co wydaje się interesujące dla badacza nowoczesnych praktyk kulturowych, jest traktowanie dźwięków wojny jako dziedzictwa kulturowego i szczególne ich funkcjonowanie $\mathrm{w}$ ramach nowoczesnej audiosfery miejskiej. Przykładem tego może być choćby coroczne uruchamianie warszawskich syren o godzinie "W" w czasie obchodów powstania warszawskiego, ale także np. wspólne słuchanie i śpiewanie „zakazanych piosenek” z tego czasu. W tej praktyce audytywnej dźwięk stanowi dziedzictwo kulturowe, zachowywane i pielęgnowane na równi z zabytkami architektury, a nawet umożliwiające od-grywanie przeszłości przez jej współczesnych czytelników/słuchaczy. W ten sposób dźwięk - syreny, piosenki, ale przecież w innym kontekście także dzwonu, hejnału czy ulicznego grajka - staje się dźwiękowym znakiem (soundmark, analogicznie do landmark stanowiącym o topografii miasta) kształtującym wyróżnialny pejzaż dźwiękowy miasta.

Nawet [bowiem - dop. K.S.] w zwartej miejskiej zabudowie oraz zatłoczonym pejzażu dźwiękowym współczesnych metropolii, wyrazisty brzmieniowo dźwięk dzwonów ma w dalszym ciągu znaczenie wyróżnione i szczególne. Jak pisze R. Murray Schafer, podobnie jak w obrazie urbanistycznym miasta istnieją elementy dominujące, świadczące o ich społecznej funkcji i statusie (stanowią je np. wieże kościelne, kominy fabryczne, drapacze chmur), tak i w miejskim pejzażu dźwiękowym pojawiają się odgłosy charakterystyczne i znaczące. Za takie Schafer uznaje przede wszystkim dzwony kościelne oraz syreny. Oba odgłosy, wyróżniając się i dominując w pejzażu fonicznym, pełnią ważną, choć w obu wypadkach odmienną, rolę społeczną. [Jak zauważa Schafer - dop. K.S.] „Syrena oznajmia niebezpieczeństwo; jest to dźwięk działający odśrodkowo, zaprojektowany tak, aby rozpędzać ludzi z drogi. Natomiast dzwon kościelny ześrodkowuje: przyciąga i jednoczy społeczność" 26 .

25 R. Murray Schafer, The soundscape: our sonic environment and the tuning of the world, Rochester 1994, s. 10.

26 R. Losiak, Recepcja dźwięków świątyń we wspótczesnym krajobrazie fonicznym miasta, „Niematerialne Wartości Krajobrazów Kulturowych. Prace Komisji Krajobrazu Kulturowego" 2011, 
Syrena uruchamiana każdego 1 sierpnia w Warszawie staje się nie tylko audytywnym aktem pamięci, ale również dźwiękową ikoną (sonic icon), akustycznym symbolem przywołującym na mocy skojarzenia i powtarzalności doświadczenie drugiej wojny światowej. Jeśli dzwon „,[w]edług Schafera jest sygnałem religijnym pełniącym ważną rolę $\mathrm{w}$ »definiowaniu « (czyli »kształtowaniu«) tradycyjnych społeczności akustycznych" ${ }^{27}$, to syrena czy "zakazana piosenka” staje się w przestrzeni dzisiejszej Warszawy audytywnym symbolem historycznym, określającym i spajającym akustyczną społeczność mieszkańców miasta i turystów zainteresowanych jego historią. Podobnie jak krakowski hejnał, choć obdarzony innymi znaczeniami, kształtuje praktyki słuchania w przestrzeni miejskiej.

Takie własności unikalnych dźwięków rozważa Fran Tonkiss, nazywając charakterystyczne dla danych miejsc własności audytywnego pejzażu mianem aural postcards, dźwiękowych pocztówek, które - podobnie jak te obrazowo-werbalne - przedstawiają reprezentatywne dla miasta elementy dziedzictwa kulturowego. Tonkiss rozważa memorialne własności dźwięku, pisząc:

Słuchanie pozostaje również w szczególnym związku z pamiętaniem. Może być, jak powiedział Benjamin, istotą pamięci. Przeszłość przychodzi do nas w swoich najbardziej spontanicznych, bezpośrednich i sensualnych formach, nie $\mathrm{w}$ sztuczności fotografii $\mathrm{z}$ podróży, lecz $\mathrm{w}$ nagłych, na pół pamiętanych dźwiękach ${ }^{28}$.

Dźwięk ma siłę przywołać wspomnienia, ale też stać się nośnikiem historii, audytywnym miejscem pamięci, a nawet postpamięci. Choć bowiem

nr 15, s. 45. Autor analizuje odmienne role, jakie te dwa źródła dźwięku pełnią w dźwiękowym pejzażu miejskim: „Porównanie odgłosów dzwonów kościelnych oraz dźwięków syreny (alarmowej, fabrycznej, ratunkowej) wiele wnosi do rozważań na temat percepcji i znaczenia dźwięków dzwonów w audiosferze. W idei dzwonu, zarówno w jego formie geometrycznej, jak i dźwiękowej, dominuje wrażenie owalności i symetrii. Dźwięki dzwonu, wzbudzane przez środkowo zawieszone pod nim serce, rozchodzą się we wszystkich kierunkach równomiernie. Tych cech nie można przypisać syrenie, która i w swym wyglądzie (tuby, głośnika), i kierunkowej charakterystyce, działa $\mathrm{w}$ ograniczonym wycinku przestrzeni, a jej brzmienie jest przenikliwe i rozpraszające. Oprócz tego istotny wydaje się w obu wypadkach aspekt percepcji wysokości. Dźwięk dzwonu zazwyczaj postrzegany jest jako spływający z góry, dominujący nad miastem, unoszący się ponad nim; dźwięk syreny natomiast jest poziomy, dobiega $\mathrm{z}$ niewielkiej wysokości, funkcjonuje w przestrzeni horyzontalnej - podczas gdy dźwięk dzwonu jest bardziej "wertykalny«" (tamże, s. 45).

27 S. Bernat, Krajobraz dźwiękowy jutra, „Niematerialne Wartości Krajobrazów Kulturowych. Prace Komisji Krajobrazu Kulturowego" 2011, nr 15, s. 194.

28 F. Tonkiss, Aural Postcards. Sound, Memory and the City, w: The Auditory Culture Reader, eds. M. Bull, L. Back, Bloomsbury Academic 2004, s. 307 [podkr. - K.S.]. 
propozycja Marianne Hirsch i jej komentatorów skupia się przede wszystkim na wizualnym aspekcie dziedziczenia traumy, to przecież dźwięk jest jednym z najsilniejszych bodźców, który także, poprzez przekazywaną narrację, wzbudza silne emocje i przywołuje strzępy obrazów przeszłości.

Tę intuicję wyraża najnowsza literatura reprezentująca doświadczenie postpamięciowe. Adam Zagajewski pisze o krakowskim Kazimierzu, że rozbrzmiewa „szeptami i jękami w różnych językach, w jidysz, po hebrajsku, po polsku, niemiecku, a także $\mathrm{w}$ języku nieludzkiego bólu" ${ }^{29}$. We współczesnych narracjach o przeszłości miast, gdzie tak ważną i już po wielekroć przywoływaną metaforą jest palimpsest, zdarzają się i takie ujęcia, które - jak w przypadku eseju Zagajewskiego - dowartościowują także akustyczny wariant tej figury: miasto jako płytę gramofonową z nagranymi dźwiękami przeszłości. Te zaś mogą zostać usłyszane przy odpowiednich staraniach współczesnych podmiotów praktyk audytywnych. Tak dzieje się choćby w powieści Tak to ten Jerzego Sosnowskiego. Propozycja Schafera pozwala widzieć w stworzonej przez autora audiosferze dzisiejszego Kołobrzegu specyficzną dla nadmorskiej wspólnoty przestrzeń dźwiękową, związaną z doświadczeniem historycznym XX wieku; u Sosnowskiego naznaczona jest ona obecnością widm przybywających z dwudziestowiecznej (nazistowskiej i radzieckiej) historii Kolbergu-Kołobrzegu i nawiedzających jego współczesnych mieszkańców. I choć urbanistyczny palimpsest, rozumiany jako wielowarstwowość także materialnych form przestrzennych, które skrywają dawniejsze, zamazane znaki, jest jedną z podstawowych figur współczesnej wyobraźni historycznej, Sosnowskiemu udaje się wprowadzić drobne przesunięcia, wzbogacając tym samym literackie reprezentacje doświadczenia postpamięci o wymiar akustyczny. Uczynienie centrum spacjalnym powieści lokalnej rozgłośni pozwala nie tylko zmodernizować sztafaż znany z estetyki grozy, w jakiej utrzymana jest książka, ale i zwerbalizować specyfikę doświadczenia urazu, które - niczym prawie niesłyszalny, ale ustawicznie obecny szmer przenika wszystkie, zróżnicowane w narracji przez dywersyfikację gatunków wypowiedzi, aspekty małomiejskiej codzienności, pozostając wszak niewidzialnym. Uchwycony przez bohatera nocą, na pustej plaży głos duchów jest zatem dźwiękowym śladem wypartego, ale także - elementem całości krajobrazu (sound/land-scape) jako przestrzeni znaczącej.

Audytywny wymiar doświadczania historii dowartościowuje polska literatura współczesna, ale nie tylko. Coraz głośniej rozbrzmiewają akademickie dyskusje wokół problemu zachowania pejzażu dźwiękowego jako elementu

29 A. Zagajewski, W cudzym pięknie, Kraków 1998, s. 71. 
dziedzictwa kultury, rozwijają się nowe dziedziny refleksji, takie jak geografia zmysłów, ekologia dźwięku czy audioetnografia. Trend ten uwidacznia się również $\mathrm{w}$ polityce miejsca, która zaczęła zwracać uwagę zarówno na artystyczne projekty zapisu dźwięków miasta, jak i świadome kształtowanie jego audytywnego pejzażu, choćby przez kreowanie audytywnych pocztówek. Dźwięk będący audio-miejscem pamięci doceniły muzea, jako tło wystaw emitując odgłosy przeszłości, a doskonałym przykładem kulturowego i historycznego awansu audiosfery wydaje się pierwszy dramat wojenny non-fiction, jakim jest udźwiękowiony obraz found footage Powstanie Warszawskie.

\section{Wartime Soundscape and Auditive Activity (Then and Now)}

\section{Summary}

The text presents a soudscape analysis of World War II. Here, the term soundscape is understood, after R. Murray Schafer, as acoustic sphere of a place and of its human community which becomes a part of intangible cultural heritage. The analysed soundscape involves wartime audio sphere of both sound senders and recipients. In order to reconstruct the aural world from the years 1939-1945, the article's author uses autobiographic texts by such writers as Białoszewski, Głowiński, Ligocka, Nałkowska, and Waniek. Further, she later demonstrates the contemporary references to wartime soundscape, and reveals how they function to construct both historical memorials and political history.

Keywords: World War II, soundscape, sonic icons, aural postcards, auditive practices, intangible cultural heritage, memorial site 